\title{
Correction to: Characterization of Creatine Kinase Levels in Tofacitinib-Treated Patients with Ulcerative Colitis: Results from Clinical Trials
}

\author{
Remo Panaccione ${ }^{1}$ (D) John D. Isaacs ${ }^{2} \cdot$ Lea Ann Chen ${ }^{3} \cdot$ Wenjin Wang ${ }^{4} \cdot$ Amy Marren $^{4} \cdot K_{\text {Kenneth Kwok }}^{5} \cdot$ Lisy Wang $^{6}$. \\ Gary Chan ${ }^{4}$. Chinyu Su ${ }^{4}$
}

Published online: 10 October 2020

(c) Tha Author(s) 2020

\section{Correction to: Digestive Diseases and Sciences https://doi.org/10.1007/s10620-020-06560-4}

The article "Characterization of Creatine Kinase Levels in Tofacitinib-Treated Patients with Ulcerative Colitis: Results from Clinical Trials", written by Remo Panaccione, John D. Isaacs, Lea Ann Chen, Wenjin Wang, Amy Marren, Kenneth Kwok, Lisy Wang, Gary Chan and Chinyu Su, was originally published electronically on the publisher's internet portal on 20 August 2020 without open access. With the author(s)' decision to opt for Open Choice the copyright of the article changed on 21 September 2020 to (C) The Author(s) 2020 and the article is forthwith distributed under a Creative Commons Attribution-NonCommercial 4.0 International License, which permits any non-commercial use, sharing, adaptation, distribution and reproduction in any medium or format, as long as you give appropriate credit to

The original article can be found online at https://doi.org/10.1007/ s10620-020-06560-4.

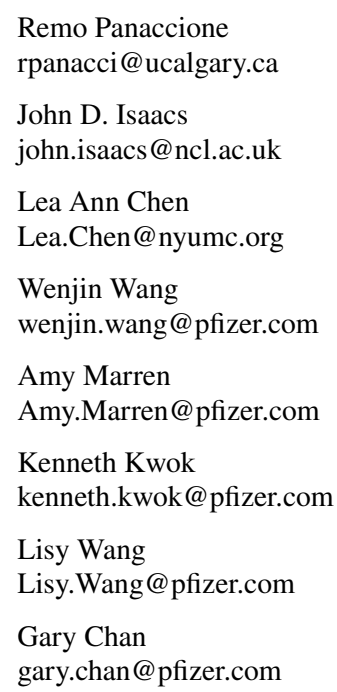

the original author(s) and the source, provide a link to the Creative Commons licence, and indicate if changes were made. The images or other third party material in this article are included in the article's Creative Commons licence, unless indicated otherwise in a credit line to the material. If material is not included in the article's Creative Commons licence and your intended use is not permitted by statutory regulation or exceeds the permitted use, you will need to obtain permission directly from the copyright holder. To view a copy of this licence, visit http://creativecommons .org/licenses/by-nc/4.0/.

The original article has been corrected.

Open Access This article is licensed under a Creative Commons Attribution-NonCommercial 4.0 International License, which permits any non-commercial use, sharing, adaptation, distribution and reproduction in any medium or format, as long as you give appropriate credit to the original author(s) and the source, provide a link to the Creative Commons licence, and indicate if changes were made. The images or other third party material in this article are included in the article's Creative Commons licence, unless indicated otherwise in a credit line to the

\section{Chinyu Su}

chinyu.su@pfizer.com

1 Department of Medicine, University of Calgary, 3330 Hospital Drive NW, Calgary, AB T2N 4N1, Canada

2 Translational and Clinical Research Institute, Newcastle University and Musculoskeletal Unit, Newcastle upon Tyne Hospitals NHS Foundation Trust, Newcastle upon Tyne, UK

3 New York University School of Medicine, New York, NY, USA

4 Inflammation and Immunology, Pfizer Inc, Collegeville, PA, USA

5 Inflammation and Immunology, Pfizer Inc, New York, NY, USA

6 Inflammation and Immunology, Pfizer Inc, Groton, CT, USA 
material. If material is not included in the article's Creative Commons licence and your intended use is not permitted by statutory regulation or exceeds the permitted use, you will need to obtain permission directly from the copyright holder. To view a copy of this licence, visit http://creativecommons.org/licenses/by-nc/4.0/.
Publisher's Note Springer Nature remains neutral with regard to jurisdictional claims in published maps and institutional affiliations. 